\title{
Effect of nifedipine on arterial hypoxaemia occurring after methacholine challenge in asthma
}

\author{
E BALLESTER, J ROCA, R RODRIGUEZ-ROISIN, A AGUSTI-VIDAL \\ From the Servei de Pneumologia, Hospital Clinic, Faculty of Medicine, University of Barcelona, Spain
}

ABSTRACT To investigate whether the effects of nifedipine on methacholine induced bronchoconstriction could impair pulmonary gas exchange in bronchial asthma a randomised, double blind, crossover study in 13 symptom free asthmatic subjects was designed. Each patient underwent a methacholine bronchial challenge test on two separate days one week apart, after having either oral nifedipine ( $20 \mathrm{mg}$ thrice daily) or placebo for three days. Arterial blood gases were measured before and after methacholine challenge in nine subjects. Prechallenge values of forced expiratory volume in one second $\left(\mathrm{FEV}_{1}\right)$ and arterial oxygen tension $\left(\mathrm{PaO}_{2}\right)$ were similar after nifedipine and after placebo. After challenge, the cumulative doses of methacholine required to produce a $20 \%$ fall in $\mathrm{FEV}_{1}\left(\mathrm{PD}_{20} \mathrm{FEV}_{1}\right)$ were significantly larger after nifedipine (280 (SD 347)) cumulative breath units (CBU) than after placebo (120 (183) CBU; $\mathrm{p}<0.01)$. After challenge the fall in $\mathrm{PaO}_{2}$ values $(17.1$ $(1.6) \mathrm{mm} \mathrm{Hg} ;(2.28(0.21) \mathrm{kPa}))$ was significantly greater than after placebo $(11.7(2.4) \mathrm{mm} \mathrm{Hg} ;(1.56$ $(0.32) \mathrm{kPa}) \mathrm{p}<0.03)$. Our data show that although oral nifedipine significantly reduces airway reactivity in patients with mild bronchial asthma, it also adversely affects pulmonary gas exchange, resulting in a lowered postchallenge $\mathrm{PaO}_{2}$, probably because of worsening ventilation-perfusion relationships.

There is increasing interest in the effects of calcium channel blocking agents on airway smooth muscle contraction. ${ }^{12}$ It has been postulated that the stimuli that provoke bronchoconstriction activate mechanisms of calcium ion transport into the cell with resulting contraction of airway smooth muscle. It has been observed both in vivo and in vitro that calcium blocking agents attenuate bronchial reactivity ${ }^{3}$ but the exact mechanism is still a matter of controversy. There is an increasing number of agents that interfere with the transmembrane flux of calcium ions. One such is nifedipine, which is known to be a potent calcium inhibitor ${ }^{4}$ and has been successfully used in the control of angina ${ }^{5}$ and systemic hypertension. ${ }^{6}$ Because of its effects on both airway smooth muscle and the cardiovascular system, nifedipine has been proposed as the drug of choice in patients with coronary artery disease and airflow obstruction. ${ }^{78}$ Nifedipine, however, is a potent systemic and pulmonary vasodilator and its administration to patients with underlying lung disease may impair ventilation-

Address for reprint requests: Dr Robert Rodriguez-Roisin, Servei de
Pneumologia, Hospital Clinic, C/Villarroel 170, 08036 Barcelona,
Spain.

Accepted 22 November 1985 perfusion $\left(\grave{V}_{\mathrm{A}} / \mathrm{Q}\right)$ matching, resulting in a lower arterial oxygen tension $\left(\mathrm{PaO}_{2}\right) .{ }^{910}$ These considerations led us to investigate the effects of nifedipine on gas exchange and spirometric values in asymptomatic asthma. Specifically, we wished to test the hypothesis that nifedipine could alter $\mathrm{PaO}_{2}$ in asthmatic patients after methacholine challenge despite its known protective effect on bronchoconstriction. A randomised, double blind, crossover study was carried out to investigate this hypothesis.

\section{Methods}

\section{SUBJECTS}

We studied 13 symptom free non-smoking asthmatic subjects with previously documented mild clinical asthma. All satisfied the criteria for asthma proposed 0 by the American Thoracic Society, ${ }^{11}$ and gave verbal consent to participation in the study. There were eight women and five men aged 20-50 years (mean 36 (SD 8.8)). For inclusion in the study each patient was required to have an $\mathrm{FEV}_{1}$ greater than $80 \%$ of predicted value. ${ }^{12}$ At the time of the study the asthma was well controlled and stable, and all subjects were asked to withhold all medications during the period of the study. They were also requested to refrain from 
coffee, cola, and chocolate drinks for the 12 hours before testing. All subjects had previously shown either a significant response to inhalation of single dose $(25 \mathrm{mg} / \mathrm{ml})$ methacholine ${ }^{13}$ or a bronchodilator response consistent with bronchial hyperresponsiveness.

\section{LUNG FUNCTION TESTS}

Spirometric measurements (Hewlett-Packard model 47804-A) consisted of three forced vital capacity (FVC) manoeuvres initially, followed by two after each dose of methacholine provided that differences in FVC in duplicate measurements did not exceed $5 \%$; if they did, a further forced expiration was performed and the best of three $\mathrm{FEV}_{1}$ values was used.

The methacholine bronchial challenge test was performed as recommended by the American Thoracic Society. ${ }^{14}$ The necessary concentrations of methacholine were prepared from a stock solution containing $25 \mathrm{mg} / \mathrm{ml}$, (the diluents being $0.5 \% \mathrm{NaCl}, 0.275 \%$ $\mathrm{NaHCO}_{3}$, and $80 \%$ propylene glycol in water). The stock solution was renewed every two months and stored at $4^{\circ} \mathrm{C}$ until solutions were prepared. ${ }^{1516}$ The same solution was used in the two challenges carried out in each subject. The concentrations of methacholine used successively were: $0.1,0.5,1,2,5,10$, $25 \mathrm{mg} / \mathrm{ml}$, and the last concentration was repeated until the cumulative dose causing a $20 \%$ fall in FEV $\left(\mathrm{PD}_{20} \mathrm{FEV}_{1}\right)$ was reached. Methacholine was delivered by intermittent inhalation of aerosol in five nondosimeter regulated breaths via a handgrip nebuliser (DeVilbiss No 42, DeVilbiss Co, Somerset, Pennsylvania, USA), and it was administered by the same observer for all patients. Subjects were instructed to take five breaths of each methacholine concentration, beginning close to functional residual capacity and inhaling slowly to total lung capacity in a constant manner. After baseline spirometric measurements had been obtained, increasing concentrations of methacholine chloride from 0.1 to $25 \mathrm{mg} / \mathrm{ml}$ were inhaled. Each series of five inhalations was followed after three minutes by spirometric measurements, and all were obtained within six minutes of the last inhalation.

Measurements of arterial blood gas tensions and pH (Radiometer BMS3 MK2, Copenhagen) were made immediately before challenge and were repeated within four to six minutes of achieving a $20 \%$ fall in $\mathrm{FEV}_{1}$. In four patients blood gas tensions could not be obtained.

The results of methacholine challenge were analysed by constructing a dose-response curve on semilogarithmic paper. Doses were expressed as cumulative breath units (CBU). The cumulative dose at which $\mathrm{FEV}_{1}$ had deteriorated by $20 \%$ of control values was considered the provocation dose $\left(\mathbf{P D}_{\mathbf{2 0}}\right.$
$\mathrm{FEV}_{1}$ ). In two subjects (Nos 8 and 9), in whom $\mathrm{PD}_{20}$ $\mathrm{FEV}_{1}$ was not reached, results were extrapolated from the slope of the last two data points recorded. Values of arterial $\mathrm{Po}_{2}$ before and after challenge were measured and alveolar-arterial differences in oxygen tension $\left(\mathrm{PA}_{\mathrm{a}} \mathrm{aO}_{2}\right)$ were calculated on the basis of the abbreviated alveolar air equation $\left(\mathrm{PAO}_{2}=\mathrm{PiO}_{2}-\right.$ $\mathrm{PaCO}_{2} / \mathrm{R}$, an $\mathrm{R}$ value of 0.8 being assumed).

\section{STUDY DESIGN}

Patients attended the laboratory on two separate days one week apart. Tests were always performed on the same day of the week and at the same hour (1300). Before each challenge either nifedipine $(20 \mathrm{mg}$ thrice daily) or placebo capsules were administered orally for three days in randomised double blind fashion, the last dose being taken 30 to 45 minutes before methacholine challenge. Salbutamol was administered after completion of the methacholine challenge. In two cases the test was terminated prematurely, either at the subject's request (No 9) or when complaints of wheezing and chest tightness were prominent (subject 8).

\section{STA TISTICS}

Comparisons of the data obtained after administration of nifedipine and placebo were made with Student's paired $t$ test. Differences between control and baseline spirometric values in each methacholine challenge were analysed by one way analysis of variance (one way ANOVA). Results are expressed as means with standard deviations in parentheses. Correlations between changes in either $\mathrm{PaO}_{2}$ or $\mathrm{PA}_{\mathrm{A}} \mathrm{aO}_{2}$ before and after challenge following each drug and the respective $\mathrm{PD}_{20} \mathrm{FEV}_{1}$ values (expressed as CBU) were analysed with Spearman's test.

\section{Results}

SPIROMETRIC MEASUREMENTS (table)

There were no significant differences in $\mathrm{FEV}_{1}$ values between control (mean $3.13(0.6) 1$ ) and the baseline values recorded on either nifedipine $(3.15(0.6) 1)$ or placebo (3.11 (0.58)1) days. Mean values for $\mathrm{PD}_{20}$ $\mathrm{FEV}_{1}$ after nifedipine were significantly higher (280 (347) CBU) than after placebo (120 (183) CBU; p < 0.01). All except one patient (No 11) showed decreased bronchomotor responsiveness after nifedipine, as judged by an increased value of CBU necessary to achieve a $20 \%$ fall in $\mathrm{FEV}_{1}$. In the nine subjects from whom blood gas data were obtained, post challenge $\mathrm{FEV}_{1}$ values after nifedipine or placebo were similar $(2.66(0.3) 1$ and $2.61(0.3) 1$ respectively). Individual values of $\mathrm{PD}_{20} \quad \mathrm{FEV}_{1}$ showed large interindividual differences in airway reactivity. 


\section{ARTERIAL BLOOD GAS MEASUREMENTS}

$\mathrm{PaO}_{2}$ measurements were available for nine subjects. No significant differences were observed between baseline $\mathrm{PaO}_{2}$ values after nifedipine and after placebo (see table). In contrast, after challenge $\mathrm{PaO}_{2}$ values after nifedipine were significantly lower and $\mathrm{PA}_{\mathrm{A}} \mathrm{OO}_{2}$ values significantly higher than the corresponding values after placebo $(p<0.005)$. Moreover, differences between $\mathrm{PaO}_{2}$ values before and after challenge showed a significantly larger fall after nifedipine (17.1 (1.6) $\mathrm{mm} \mathrm{Hg} ; 2.28(0.21) \mathrm{kPa}$ ) than after placebo (11.7 (2.4) mm Hg; 1.56 (0.32) kPa: p < 0.03). Similarly, the increase in $\mathrm{PA}_{-} \mathrm{aO}_{2}$ was significantly greater after nifedipine than after placebo $(17.4(6.3) \mathrm{mm} \mathrm{Hg}$; 2.32 (0.84) $\mathrm{kPa} v 11.8(8.6) \mathrm{mm} \mathrm{Hg} ; 1.57$ (1.15) $\mathrm{kPa}$ : $\mathrm{p}<0.02)$.

No significant correlation was found when the differences in $\mathrm{PaO}_{2}$ or in $\mathrm{PA}_{\mathrm{A}} \mathrm{aO}_{2}$ values before and after methacholine challenge following either nifedipine or placebo were plotted against the values of $\mathrm{PD}_{20} \mathrm{FEV}_{1}$.

\section{Discussion}

Our data show that nifedipine has a protective effect on airway reactivity, but this potentially beneficial effect is accompanied by a deterioration in pulmonary gas exchange resulting in hypoxaemia. The latter finding suggests that nifedipine worsens the ventilation-perfusion (VA/Q) inequalities already present in symptom free patients with bronchial asthma. ${ }^{17}$

Nifedipine had no apparent effect on resting airway smooth muscle tone, as judged by the lack of significant differences between control and prechallenge (baseline) $\mathrm{FEV}_{1}$ after either nifedipine and placebo, which is in keeping with the results of earlier studies. ${ }^{18}$ The absence of a bronchodilating effect in our patients after short-term treatment with nifedipine might be explained in part by their near normal baseline flow rates (all patients had an FEV greater than $80 \%$ of predicted values).

Previous studies have shown an inhibitory effect of calcium channel blockers, particularly nifedipine, on airway smooth muscle. The precise mechanism is unknown, but inhibition of mediator release or of calcium ion entry into airway smooth muscle cells (or both) has been invoked. Since Cerrina et $a^{3}$ reported the protective effect of nifedipine in exercise induced bronchoconstriction, evidence supporting this beneficial effect has been produced in bronchoconstriction induced by exercise, ${ }^{19}$ antigen, ${ }^{20}$ and histamine. ${ }^{2122}$ Our results with methacholine confirm these studies, since oral nifedipine reduced methacholine induced bronchoconstriction in all but one patient.

In patients with asthma a low $\mathrm{PaO}_{2}$ may result from the existence of poorly ventilated areas of low $\dot{V}_{A} / Q$ ratio. ${ }^{17}$ Drugs that alter $\dot{V}_{A} / Q$ matching may impair gas exchange. It has, for instance, been shown that the administration of vasodilator drugs to patients with generalised airflow obstruction may aggravate pre-existing hypoxaemia. ${ }^{10}$ In addition, nifedipine is known to reduce hypoxic pulmonary vasoconstriction both in animal models ${ }^{23}$ and in patients with acute respiratory failure ${ }^{24}$ or chronic airflow obstruction. ${ }^{1025}$ There have so far been no other reports of the effects of nifedipine on pulmonary gas

Spirometric and blood gas data before (baseline) and after methacholine challenge following each drug

\begin{tabular}{|c|c|c|c|c|c|c|c|c|c|c|c|c|c|c|}
\hline \multirow{3}{*}{$\begin{array}{l}\text { Subject } \\
\text { No }\end{array}$} & \multicolumn{7}{|c|}{ Nifedipine } & \multicolumn{7}{|c|}{ Placebo } \\
\hline & \multicolumn{3}{|c|}{ Before challenge } & \multicolumn{4}{|c|}{ After challenge } & \multicolumn{3}{|c|}{ Before challenge } & \multicolumn{4}{|c|}{ After challenge } \\
\hline & $\begin{array}{l}\overline{F E V_{1}} \\
(I)\end{array}$ & $\begin{array}{l}\mathrm{PaO}_{2} \\
(\mathrm{~mm} \mathrm{Hg})\end{array}$ & $\begin{array}{l}P_{A-a O_{2}} \\
(m m \boldsymbol{H g})\end{array}$ & $\begin{array}{l}F E V_{1} \\
(1)\end{array}$ & $\begin{array}{l}P D_{20} \\
(C B U)\end{array}$ & $\begin{array}{l}\mathrm{PaO}_{2} \\
(\mathrm{~mm} \mathrm{Hg})\end{array}$ & $\begin{array}{l}{\mathrm{PA}-a \mathrm{O}_{2}}_{2} \\
(\mathrm{~mm} \mathrm{Hg})\end{array}$ & $\begin{array}{l}\overline{F E V_{1}} \\
(1)\end{array}$ & $\begin{array}{l}\mathrm{PaO}_{2} \\
(\mathrm{~mm} \mathrm{Hg})\end{array}$ & $\begin{array}{l}P_{A-a O_{2}} \\
(m m \mathrm{Hg})\end{array}$ & $\begin{array}{l}\overline{F E V_{1}} \\
(1)\end{array}$ & $\begin{array}{l}P D_{20} \\
(C B U)\end{array}$ & $\begin{array}{l}\mathrm{PaO}_{2} \\
(\mathrm{~mm} \mathrm{Hg})\end{array}$ & $\begin{array}{l}P_{A-a O_{2}} \\
(\mathrm{~mm} \mathrm{Hg}\end{array}$ \\
\hline $\begin{array}{c}1 \\
2 \\
3 \\
4 \\
5 \\
6 \\
7 \\
8 \\
9 \\
10 \\
11 \\
12 \\
13 \\
\text { Mean } \\
\text { (SD) }\end{array}$ & $\begin{array}{c}2.37 \\
2.57 \\
2.78 \\
4.00 \\
2.79 \\
3.76 \\
4.25 \\
3.51 \\
2.03 \\
3.06 \\
3.52 \\
3.21 \\
3.15 \\
3.15 \\
(0.64)\end{array}$ & $\begin{array}{l}\text { ND } \\
\text { ND } \\
94.8 \\
71.7 \\
78.1 \\
75.1 \\
80.6 \\
80.3 \\
\text { ND } \\
\text { ND } \\
84.9 \\
66.8 \\
72.7 \\
78.5 \\
(8.3)\end{array}$ & $\begin{array}{l}\text { ND } \\
\text { ND } \\
18.3 \\
37.5 \\
29.1 \\
25.8 \\
25.2 \\
24.8 \\
\text { ND } \\
\text { ND } \\
26.3 \\
39.6 \\
37.7 \\
29.4 \\
(7.3)\end{array}$ & $\begin{array}{l}1.94 \\
1.82 \\
2.25 \\
3.18 \\
2.21 \\
2.81 \\
2.87 \\
3.05 \\
1.86 \\
2.39 \\
2.64 \\
2.54 \\
2.37 \\
2.46 \\
(0.4)\end{array}$ & $\begin{array}{r}260 \\
12 \\
232 \\
88 \\
440 \\
54 \\
48 \\
1000 \\
1000 \\
75 \\
13 \\
360 \\
60 \\
280^{*} \\
(347)\end{array}$ & $\begin{array}{l}\text { ND } \\
\text { ND } \\
78.0 \\
55.1 \\
62.1 \\
54.1 \\
62.1 \\
64.8 \\
\text { ND } \\
\text { ND } \\
60.4 \\
59.8 \\
56.6 \\
61.4 \$ \\
(7.1)\end{array}$ & $\begin{array}{l}\text { ND } \\
\text { ND } \\
28.9 \\
52.0 \\
49.3 \\
48.0 \\
41.5 \\
43.8 \\
\text { ND } \\
\text { ND } \\
50.1 \\
45.8 \\
53.3 \\
45.8 * * \\
(7.4)\end{array}$ & $\begin{array}{c}2.44 \\
2.49 \\
2.75 \\
3.79 \\
2.96 \\
3.26 \\
4.11 \\
3.54 \\
2.02 \\
3.08 \\
3.47 \\
3.23 \\
3.38 \\
3.11 \\
(0.58)\end{array}$ & $\begin{array}{l}\text { ND } \\
\text { ND } \\
90.2 \\
74.9 \\
80.7 \\
85.1 \\
80.3 \\
80.1 \\
\text { ND } \\
\text { ND } \\
84.9 \\
65.9 \\
73.0 \\
79.4 \\
(8.1)\end{array}$ & $\begin{array}{l}\text { ND } \\
\text { ND } \\
23 \\
35.9 \\
21.1 \\
17.1 \\
26.3 \\
28.6 \\
\text { ND } \\
\text { ND } \\
21.9 \\
41.2 \\
30.2 \\
27.2 \\
(7.65)\end{array}$ & $\begin{array}{l}1.94 \\
1.88 \\
2.17 \\
3.08 \\
2.28 \\
2.53 \\
2.94 \\
2.78 \\
1.58 \\
2.37 \\
2.55 \\
2.60 \\
2.57 \\
2.40 \\
(0.58)\end{array}$ & $\begin{array}{c}41 \\
6 \\
82 \\
52 \\
74 \\
38 \\
26 \\
540 \\
520 \\
32 \\
27 \\
95 \\
28 \\
120.1^{*} \\
(183)\end{array}$ & $\begin{array}{l}\text { ND } \\
\text { ND } \\
87.1 \\
67.7 \\
65.3 \\
62.5 \\
70.6 \\
62.1 \\
\text { ND } \\
\text { ND } \\
71.4 \\
64.3 \\
60.1 \\
67.98 \\
(8.1)\end{array}$ & $\begin{array}{l}\text { ND } \\
\text { ND } \\
24 \\
41.6 \\
34.6 \\
43.3 \\
35.6 \\
45.5 \\
\text { ND } \\
\text { ND } \\
42.3 \\
40.7 \\
43.1 \\
39 * * \\
(6.65)\end{array}$ \\
\hline
\end{tabular}

*p $<0.01 ; * *$ and $\$ p<0.005$.

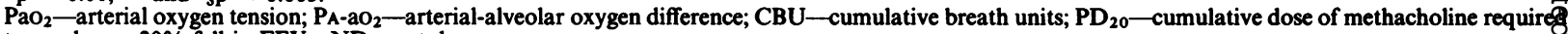
to produce a $20 \%$ fall in $\mathrm{FEV}_{1} ; \mathrm{ND}$-not done.

Conversion: traditional to SI units-Blood gas tensions: $1 \mathrm{~mm} \mathrm{Hg} \approx 0.13 \mathrm{kPa}$. 
exchange in patients with asthma.

Our study showed that baseline prechallenge values of $\mathrm{PaO}_{2}$ were similar after nifedipine and placebo, even though a lower $\mathrm{PaO}_{2}$ might have been expected after nifedipine as a result of impairment in $\dot{V}_{A} / Q$ mismatching. There is, however, evidence that the systemic vasodilation that occurs with nifedipine, ${ }^{24} 26$ by increasing cardiac output, results in a raised mixed venous oxygen tension $\left(\mathrm{P}_{\bar{v}} \mathrm{O}_{2}\right)$ and in this way may offset the expected fall in arterial $\mathrm{PO}_{2}$.

The greater reduction in postchallenge $\mathrm{PaO}_{2}$ after nifedipine than after placebo is probably related to further impairment in $\dot{V}_{A} / Q$ abnormalities. Whether inhibition of hypoxic pulmonary vasoconstriction may explain part of the reduced $\mathrm{PaO}_{2}$ remains to be elucidated. Presumably any simultaneous increase in cardiac output was insufficient to compensate for the altered efficiency of pulmonary gas exchange provoked by methacholine challenge. There were no significant differences in postchallenge $\mathrm{FEV}_{1}$ values after nifedipine and after placebo. Neither were there any significant correlations between the changes in $\mathrm{PaO}_{2}$ and $\mathrm{PA}_{-}-\mathrm{aO}_{2}$ that followed methacholine challenge and the doses of methacholine. This finding is particularly important as it suggests that the higher methacholine concentrations used after nifedipine cannot be implicated in the lower $\mathrm{PaO}_{2}$ values achieved. The data therefore suggest that nifedipine exacerbates hypoxaemia in patients with mild bronchial asthma when they are submitted to methacholine challenge.

It is self-evident that worsening of hypoxaemia associated with nifedipine is potentially an important side effect in patients with reversible airways obstruction who develop acute bronchoconstriction. In patients with associated cardiovascular diseases, such as angina pectoris, such an effect might be particularly serious. Our conclusions therefore appear clearly at variance with those of a recent report, ${ }^{27}$ in which the safety of nifedipine was assessed only on spirometric grounds in patients with asthma, chronic obstructive lung disease, and coronary artery disease. In that study no adverse effects were observed in lung function tests but $\mathrm{PaO}_{2}$ was not measured. A decrease in $\mathrm{PaO}_{2}$ within the range observed in our study in a patient without underlying hypoxaemia is unlikely to be clinically important. A similar reduction of $\mathrm{PaO}_{2}$ in a patient with pre-existing hypoxaemia, however, could be hazardous, although we do not know whether methacholine induced bronchoconstriction represents a perfect model of spontaneous exacerbations of asthma.

We are indebted to Teresa Lecha, Concepción Gistau, and Felip Burgos for their technical assistance; to Lourdes Carbonell from the Department of Pharma- cology for help in preparing methacholine solutions, to Neus Oriola for secretarial assistance, and to Drs Antonio Reyes and Peter Wagner for their careful review and helpful suggestions respectively. We are also indebted to Laboratoris BOI for supplying nifedipine and placebo capsules. The work was supported by grants from CAICYT (1787/82), the Joint US-Spain Committee (8309185), SEPAR (1983), and Laboratoris BOI.

\section{References}

$1 \mathrm{McFadden}$ ER. Calcium-channel blocking agents and asthma. Ann Intern Med 1981;95:232-3.

2 Fanta CH, Drazen JM. Calcium blockers and bronchoconstriction. Am Rev Respir Dis 1983;127:673-4.

3 Cerrine J, Denjean A, Alexandre G, et al. Inhibition of exercise-induced asthma by a calcium antagonist, nifedipine. Am Rev Respir Dis 1981;123:156-60.

4 Triggle DJ, Swany VC. Pharmacology of agents that affect calcium. Agonists and antagonists. Chest 1980;78,suppl:174-9.

5 Braunwald E. Mechanisms of action of calcium-channelblocking agents. $N$ Engl J Med 1982;307:1618-27.

6 Bertel O, Conen D, Radu EW, et al. Nifedipine in hypertensive emergencies. Br Med J 1983;286:19-21.

7 Gonzalez JM, Morice RC, Bloom K, et al. Inhibition of airway reactivity by nifedipine in patients with coronary artery disease. Am Rev Respir Dis 1983;127:155-7.

8 Townley RG. Calcium channel antagonists in coronary artery spasm and bronchial asthma. Chest 1982, 82:401-3.

9 Dantzker DR, Bower JS. Pulmonary vascular tone improves $\dot{V}_{A} / Q$ matching in obliterative pulmonary hypertension. J Appl Physiol 1981;51:607-13.

10 Melot C, Hallemans R, Naeije R, Mols P, Lejeune P. Deleterious effect of nifedipine on pulmonary gas exchange in chronic obstructive pulmonary disease. Am Rev Respir Dis 1984;130:612-6.

11 American Thoracic Society. Definition and classification of chronic bronchitis asthma and pulmonary emphysema. Am Rev Respir Dis 1962;85:762-8.

12 Roca J, Sanchis J, Agusti-Vidal A, et al. Spirometric reference values from a Mediterranean population. Bull Eur Physiopath Respir (in press).

13 Chathman M, Bleecker ER, Norman P, Smith PL, Mason P. A screening test for airway reactivity. An abbreviated methacholine inhalation challenge. Chest 1982;82:15-8.

14 Cropp GJA, Bernstein IL, Boushey HA, et al. Guidelines for bronchial inhalation challenges with pharmacologic and antigenic agents. ATS News 1980;6:11-9.

15 Pratter MR, Woodman TF, Irwin RS, Johnson B. Stability of stored methacholine chloride solutions. Am Rev Respir Dis 1982;126:717-9.

16 Michael Alberts W, Ferguson PR, Ramsdell JW. Preparation and handling of methacholine chloride testing solutions. Am Rev Respir Dis 1983;127:350-1.

17 Wagner PD, Dantzker DR, Iacovoni VE, Tomlin WC, West JB. Ventilation-perfusion inequality in asymptomatic asthma. Am Rev Respir Dis 1978;118:511-24.

18 Williams DO, Barnes PJ, Vickers HP, Rudolf M. Effect 
of nifedipine on bronchomotor tone and histamine reactivity in asthma. $\mathrm{Br}$ Med $J$ 1981;283:348.

19 Barnes PJ, Wilson NM, Brown MJ. A calcium antagonist, modifies exercise-induced asthma. Thorax 1981;36: 726-30.

20 Henderson AF, Heaton RW, Dunlop LS, Costello JF. Effects of nifedipine on antigen-induced bronchoconstriction. Am Rev Respir Dis 1983;127:549-53.

21 Fanta CH, Venugopalan CS, Lacouture PG, Drazen JM. Inhibition of bronchoconstriction in the guinea pig by a calcium channel blocker, nifedipine. Am Rev Respir Dis 1982;125:61-6.

22 Corris PA, Nariman S, Gibson J. Nifedipine in the prevention of asthma induced by exercise and histamine. Am Rev Respir Dis 1983;128:991-2.

23 Kennedy T, Summer W. Inhibition of hypoxic pul- monary vasoconstriction by nifedipine. Am $J$ Cardiol 1982;50:864-8.

24 Simonneau G, Escorrou P, Duroux P, Lockhart A. Inhibition of pulmonary vasoconstriction by nifedipine. N Engl J Med 1981;304:1582-5.

25 Kennedy T, Michael J, Huang C, et al. Nifedipine inhibits hypoxic pulmonary vasoconstriction during rest and exercise in patients with chronic obstructive pulmonary disease. Am Rev Respir Dis 1984;129: 544-51.

26 Naeije R, Melot C, Mols P, Hallemans R. Effects of vasodilators on hypoxic pulmonary vasoconstriction in normal man. Chest 1982;82:404-10.

27 Nair N, Townley RG, Bewtra A, Nair CK. Safety of nifedipine in subjects with bronchial asthma and COPD. Chest 1984;86:515-8. 